\title{
Non-negative word order in Breton: maintaining verb-second ${ }^{1}$
}

\author{
Holly J. Kennard, University of Oxford \\ holly.kennard@ling-phil.ox.ac.uk
}

\section{ABSTRACT}

This article examines variation in Breton word order patterns in non-negative utterances across speakers of different ages. Not only has there been some disagreement on how best to characterise unmarked word order in Breton, it has also been claimed that younger speakers of so-called Neo-Breton overuse subject-initial word order under influence from French. Data from fieldwork provide a complex picture of word order variability. This seems to be driven by a number of factors, including the nature of the subject (lexical or pronominal), regional variation among older speakers, and a corresponding lack of regional features among younger speakers. Rather than overusing subject-initial word order, the Neo-Breton speakers tend to avoid this word order pattern when other word orders are available, such that the verbsecond pattern is being maintained.

KEYWORDS: Breton; word order; V2; variation; new speakers

\section{INTRODUCTION}

In many ways, Breton stands alone among the Insular Celtic languages as the 'odd one out'. While it shares some typically Celtic features, such as initial consonant mutation, inflected prepositions, and the use of preverbal particles, it differs by being spoken in mainland Europe, possessing both a verb 'to have' and a corresponding 'have-perfect', and not having a basic surface VSO word order in affirmative main clauses (Heine \& Kuteva 2005). It is this last feature which is the subject of discussion here. In Welsh, Breton's closest living relative, the unmarked word order places the verb in initial position, but in Breton this is ungrammatical.

Verb-initial word order

a. Welsh

$$
\text { prynodd Elin dorth o fara }
$$

buy.PAST.3SG Elin loaf of bread

'Elin bought a loaf of bread.'

b. Breton
i. Elen a brenas bara
Elen PRT buy.PAST.3Sg bread
'Elen bought some bread.'

ii. *brenas Elen bara

\footnotetext{
1 The fieldwork for this study was carried out with the help of a travel grant from Jesus College, Oxford. I would like to thank Aditi Lahiri for her invaluable help and advice on this work, and Charlotte Hemmings and Beinan Zhou for their comments on earlier drafts. I am also grateful to three anonymous reviewers for their detailed and insightful comments. All remaining errors are my own.
} 


\section{iii. *a brenas Elen bara}

The variety of word order options available in Breton has led to a great deal of discussion regarding its basic word order pattern: is it similar to the other Celtic languages, or has it been subject to influence from French?

In addition to this, Breton is an endangered language, and there was effectively a break in intergenerational transmission following the Second World War, the result of decades of political and social pressures. The number of Breton speakers is in decline, and the majority of speakers are now quite elderly (Broudic 2009). However, more recently language revitalisation efforts have led to the emergence of a new generation of speakers, many of whom have learnt Breton through immersion schooling programmes, and who may be French-dominant. In the minority language context, such speakers are sometimes termed 'new speakers'; that is, speakers who have attained proficiency in the language by means other than intergenerational transmission (see, e.g. Hornsby 2015, Jaffe 2015, 0'Rourke, et al. 2015). New speakers of Breton are known as néobretonnants, and the variety of Breton they speak as Neo-Breton.

Linguists have identified differences between the traditional Breton of older native speakers, and the Neo-Breton spoken by the younger generation. Neo-Breton is a standard variety, and is said to prefer Celtic neologisms over borrowings from French, such as kaotigell for konfitur, 'jam' (Jones 1995), but to show French influence in phonology, and to lose grammatical elements that are typical of Breton, such as inflected prepositions or interrogative particles (Hornsby 2005). The two generations of speakers often do not interact, and may find it difficult to understand one another. For many speakers, Neo-Breton simply is not 'du vrai breton' (Avezard 1999). ${ }^{2}$

In light of the variability in Breton word order patterns, an examination of how younger Breton speakers use word order is likely to be interesting, both from the point of view of understanding basic word order in Breton, and from the perspective of better understanding what characterises new speakers. To this end, Kennard (2014) examines word order in Breton negative clauses across two generations of speakers, and finds complex patterns of word order usage that do indeed show that the generations use word order differently, though perhaps not in the way that might be expected: there is not a whole-scale replacement of Breton patterns with those of French, for example. However, this is only part of the story, since it deals only with negative utterances. As a number of writers discuss (e.g., Brody 1984, Dryer 2007, Song 2012) the norm when examining word order is to focus on the most 'basic' or least 'marked' type of utterance - not usually negative utterances. With the background regarding negative utterances in place, this study therefore extends the findings of Kennard (2014) to report on basic declarative (non-negative) utterances in Breton, again across two generations of speakers, with the aim of producing a fuller picture of word order usage in Breton.

\footnotetext{
2 Literally, 'true' or 'real' Breton.
} 
The discussion is organised as follows: in section 2 the Breton word order facts are presented, together with an overview of the debate surrounding basic word order in Breton. Section 3 gives details of the fieldwork undertaken, and the results are presented in section 4 . The implications of these results are discussed in section 5, with section 6 providing some conclusions. ${ }^{3}$

\section{WORD ORDER IN BRETON}

Part of the reason that word order in Breton is so interesting to linguists is that there is a range of word order patterns available to speakers (Press 2009). Breton has a verb-second constraint in matrix clauses, so that the finite element, whether it is a main verb or an auxiliary, must appear in second position, following some other constituent. The nature of this initial constituent is essentially driven by information structure: the most relevant information appears first, in a focused position. This is often described as the 'answer to a question' appearing first: for example, the two sentences in (2) both have the meaning 'the paper is white', but a different constituent is focused in each case. The first can be thought of as the answer to 'what colour is the paper?', while the second is the response to 'what is white?'.

Word order alternation

a. gwenn eo ar paper white be.3SG DET paper 'The paper is white.'

b. ar paper zo gwenn DET paper be.UNIN white 'The paper is white.'4

(Kerrain 1995)

Breton speakers can therefore place the subject in initial position, or equally, any other element they wish to focus, such as the object or an adverbial phrase. On the surface, then, Breton word order displays a number of different patterns.

As mentioned above, unlike the other living Celtic languages, Breton does not allow a finite verb in initial position in matrix clauses (with a few exceptions, to be discussed below), although VSO is the usual word order in embedded clauses. ${ }^{5}$ However, it is possible to place a non-finite verb in initial position, followed by an inflected auxiliary. One example of this is the so-called periphrastic construction, which places the verbal noun in initial position, followed by an inflected form of ober 'to do, which acts as a 'dummy' auxiliary. This construction is an instance of $V$-fronting, or Long Head Movement, and has been discussed quite extensively in the literature regarding Breton word order. ${ }^{6}$ It is also possible to place other non-finite verb

\footnotetext{
3 This study continues work reported in Kennard (2014). For the sake of clarity, it was felt appropriate to repeat material where it is necessary for an understanding of the discussion in hand. The data are entirely new.

4 The verb bezañ 'to be' has a number of different forms. The example in (3a) contains the 3sG form of the copula $(e o)$, while ( $3 \mathrm{~b})$ has the 'uninflected' form: that used following the subject.

${ }^{5}$ Although often claimed to be ungrammatical, subject-initial word order is also attested in embedded clauses see, e.g. Varin (1979) and Hewitt (2002).

${ }^{6}$ See, for example, Borsley et al. (1996), Schafer (1997), Tallerman (1997) and Borsley \& Kathol (2000).
} 
forms in initial position. Examples are given in (3), and V-fronting will be discussed in more detail in section 5 .

(3) Constructions with an initial non-finite verb

a. Verbal noun

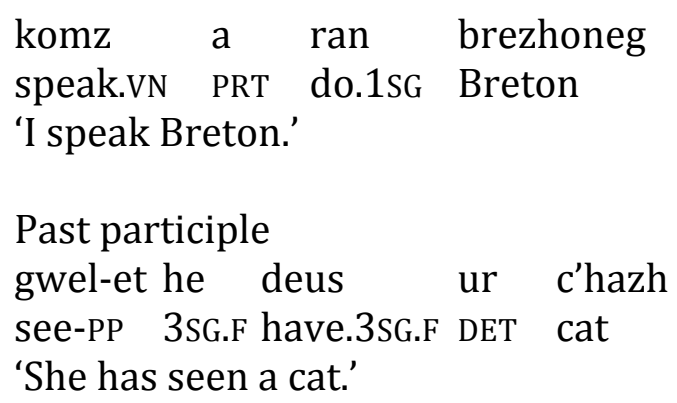

There are two other points to note from the examples given so far, which will be helpful in understanding the discussion to come. The first is that Breton, like the other Celtic languages, has a number of preverbal particles. In declarative matrix clauses, the identity of the initial constituent is the trigger for the choice of particle that follows. The particle $a$ is used following the subject, object or verbal noun (as in examples (4a-c)), while the particle $e$ is used elsewhere, such as following adverbial phrases (see $(4 \mathrm{~d})$ ). The particles in turn trigger mutation on the verb (underlined in the examples): $a$ causes lenition, while $e$ causes the mixed mutation. Note that these two particles cannot by themselves fulfil the V2 constraint by occupying the preverbal position, and the sentences in example (5) are therefore ungrammatical. Indeed, Welsh has similar preverbal particles which have been analysed as forming a constituent with the following verb (see, e.g. Willis 1998, Borsley, et al. 2007); it is possible that the Breton particles behave in the same way.

(4) Particle usage

a. Subject-initial

$$
\begin{array}{llll}
\text { me a } & \text { zebr } & \text { krampouezh } \\
\text { I } & \text { PRT } & \text { eat.3sG } & \text { pancake.PL } \\
\text { 'I eat pancakes.' } &
\end{array}
$$

b. Verbal noun-initial

$$
\begin{array}{llll}
\text { debriñ a } & \text { ran } & \text { krampouezh } \\
\text { eat.VN PRT } & \text { do.1SG } & \text { pancake.PL } \\
\text { 'I eat pancakes.' } &
\end{array}
$$

c. Object-initial

krampouezh a zebr-an

pancake.PL PRT eat-1SG

'I eat pancakes.'

d. Adverb-initial

alies e tebr-an krampouezh

often PRT eat-1SG pancake.PL

'I often eat pancakes.' 
Particles and the V2 constraint

a. *a zebran krampouezh

b. *e tebran krampouezh

Intended: 'I eat pancakes.'

The second point is that verbal agreement in Breton depends on the presence or absence (and also, in negative clauses, the position) of the subject. In non-negative matrix clauses, the verb only agrees with its subject if the subject is not present; that is, if it is an unexpressed (null) pronoun. Otherwise the verb appears in a default form, usually the third person singular, although the verb bezañ 'to be' has a special 'uninflected' form zo. There is therefore a contrast in agreement patterns in examples $4 \mathrm{a}$ and $4 \mathrm{c}$ above. (The only exception to this is the verb anavezout 'to have', which, for historical reasons, always inflects; however, this will not be relevant in the discussion to follow.) In negative clauses, the verb agrees with an unexpressed pronoun, and with an overt subject when it precedes the verb, but not when it follows the verb, as illustrated in example (6).

Agreement in negative utterances

a. Unexpressed pronoun

ne zebr -ont ket krampouezh

NEG eat -3PL NEG pancake.PL

'They do not eat pancakes.'

b. Subject preceding verb ar merc'h -ed ne zebr -ont ket krampouezh DET girl -PL NEG eat -3PL NEG pancake.PL 'The girls do not eat pancakes.'

c. Subject following verb ne zebr ket ar merc'h -ed krampouezh NEG eat.3SG NEG DET girl -PL pancake.PL 'The girls do not eat pancakes.'

This has led to the assertion that in negative clauses an initial subject is actually outside the main clausal domain, since it allows for the generalisation that there is verbal agreement only when there is no overt subject within the clause (Stump 1984).

While Breton is generally V2 in matrix clauses, there are two main exceptions to this constraint, where the finite element is permitted to appear in initial position. The first is a relatively marginal construction termed the 'go-future'. It is restricted in use, being confined mainly to eastern dialects of Breton. It combines the verb mont 'to go' with the preposition $d a$ plus the verbal noun.

\footnotetext{
7 Traditionally this word order pattern is said to place emphasis on the subject; however, Kennard (2014) finds that this can also have a neutral (wide-focus) reading for some speakers.
} 
The 'go-future'

ec'h an da zebriñ krampouezh ${ }^{8}$

PRT go.1SG to eat.VN pancake.PL

'I'm going to eat pancakes.'

(Hewitt 2002: 10)

The other exception to the V2 constraint is more widely used, and concerns the situational form of the verb bezañ 'to be', which in its third singular form is emañ. It is used to express the location of someone or something, and is also the auxiliary used to form the progressive aspect.

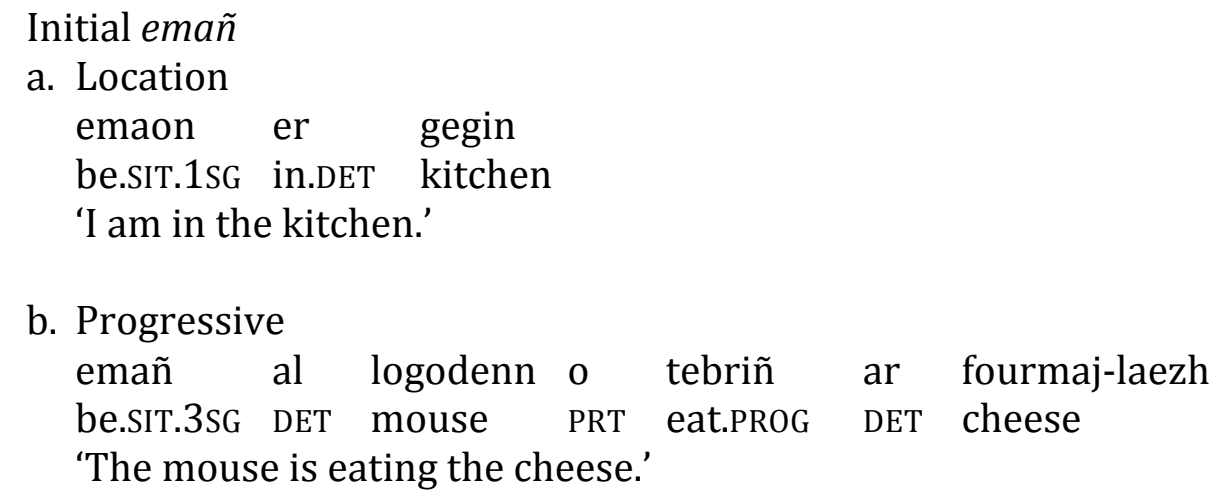

The progressive is formed by combining emañ with the progressive particle $o$ plus the verbal noun. Like the particle $e$, the progressive particle triggers mixed mutation on the verb.

\subsection{Discussion of Breton word order in the literature}

Breton word order is clearly highly flexible, but this does not entirely explain why it has been the subject of much discussion. While there are many options available to speakers, and a study of a large corpus would no doubt find a range of different word order patterns, many of these alternatives are pragmatically marked, as discussed above, with a focused initial constituent. The question still remains as to what constitutes basic word order in Breton, (if such a thing can indeed be found), that is, what word order speakers choose when there is no focused constituent, and there are therefore no other pragmatic considerations, and writers disagree on this point. ${ }^{9}$ Breton has variously been described as VSO, SVO, or simply V2, and the issues surrounding these claims will now be discussed.

Part of the confusion arises from the fact that basic word order is not (or not necessarily) the same as underlying word order. Several early accounts of Breton word order describe it as being VSO (e.g., Wojcik 1976a, Wojcik 1976b, Anderson \& Chung 1977, Anderson 1981), but as finite verb-initial word order is clearly ungrammatical in Breton (with the exceptions noted above), this might appear to ignore known facts regarding Breton word order completely. However, in all of these accounts, this analysis is qualified by the statement that main clauses are subject to some other constraint, such as topicalisation, with the result

\footnotetext{
8 The particle $e$ is usually found as $e c^{\prime} h$ before a vowel.

${ }^{9}$ In this paper, the basic word order of a language is taken to be its pragmatically neutral word order; this is not necessarily the most basic word order from a syntactic perspective, nor is it the only interpretation of 'basic word order' to be found in the literature.
} 
that surface VSO is never found. These writers are therefore referring to an underlying word order which is then subject to certain surface constraints, and this is sometimes characterised as XVSO (e.g. Stephens 1983, Hewitt 2002, Jouitteau 2010a). ${ }^{10}$

Accepting that surface VSO is highly restricted in affirmative main clauses, and that these are subject to a V2 constraint, redefines the debate regarding basic word order in Breton. As Tallerman (1997) points out, this debate is not so much centred on word order patterns in general, but on identifying the least marked initial constituent to precede the finite verb. There are two possibilities, based on word order patterns in neutral utterances: the subject, or the non-finite verb (examples repeated in (9) for ease).

a. Subject initial

$$
\begin{array}{llll}
\text { me a } & \text { gomz } & \text { brezhoneg } \\
\text { I } \quad \text { PRT } & \text { speak.3SG } & \text { Breton } \\
\text { 'I speak Breton.' } &
\end{array}
$$

b. VN-initial

$\begin{array}{llll}\text { komz } & \text { a } & \text { ran } & \text { brezhoneg } \\ \text { speak.VN PRT } & \text { do.1SG } & \text { Breton } \\ \text { 'I speak Breton.' } & \end{array}$

Varin (1979) was the first to address the issue of SVO word order in Breton, claiming that 'traditional' Breton was predominantly subject-initial, and that this could be seen not only in standard matrix clauses, but also in negative clauses and embedded clauses, which are usually said to be verb-initial. Other writers (e.g., Jouin 1984, Raney 1984) support this view, possibly in part because Varin contrasts SVO order with VSO order, which is a little misleading, since it is clear that an initial finite verb is not normally permitted in Breton. Delanoy (1990: 220) for example, writes that 'in main clauses VSO looks like a ghost and to classify Breton as a VSO language seems inadequate'.

Even disregarding this confusion about the status of $\mathrm{V}$ (finite or non-finite), there is still plenty of support for the SVO view. Heine \& Kuteva (2005) and Heine (2006) both suggest that Breton has gone from being a true V2 language to an SVO language through a process of 'pragmatic unmarking', probably under influence from French. In this process, a formerly marked word order becomes unmarked, losing its focused interpretation. In Breton, subjectinitial word order used to be marked for emphasis on the subject, but this has been lost.

In contrast, other writers claim that the most neutral word order places the verbal noun in initial position, as in example (3) (e.g., Stephens 1983, Press 1986, Hewitt 2002).

\footnotetext{
10 One exception is Timm $(1989,1991)$, who appears to claim that Breton is a surface VSO language; however, as Tallerman (1997) points out, there are a number of problems with Timm's analysis, not least the fact that she conflates finite and non-finite verbs under the single heading V. Indeed, the need to distinguish between the finite and non-finite verb is discussed by Hewitt (2002), who suggests distinguishing between the predicate (P) and the tensed element (T). While this may be a useful distinction to make, it overlooks the fact that the predicate and the tensed element can be identical, as they are in example (8a) above, and so this usage will not be followed here.
} 
Under this view, Vnfin-initial word order is a type of repair strategy: in a neutral context there is no element to receive narrow focus, but due to the V2 constraint, something must appear in the preverbal position. Using an initial non-finite verb and a dummy auxiliary solves this problem, and Vnfin-initial word order is therefore a 'neutral' word order.

Jouitteau (2007) proposes a possible explanation for these competing hypotheses, suggesting that both S-initial and Vnfin-initial word order can have a neutral, or 'wide-focus' reading in Breton. Like Heine (2006), writers such as Stephens (1982) and Schapansky (2000) have noted that SVO order in Breton is no longer restricted to a narrow focus reading on the subject, and so the utterance in $(10 \mathrm{~b})$ can have either a wide-focus or a narrow-focus reading.

Wide vs. narrow focus

a. Vnfin-initial: wide-focus

debriñ a ra Soazig
eat.VN PRT do.3sG Soazig
'Soancake.PL eats pancakes.'

b. S-initial: wide or narrow focus
Soazig a zebr krampouezh
Soazig PRT eat.3SG pancake.PL
'Soazig eats pancakes.'
wide focus
'It is Soazig who eats pancakes.'
narrow focus on subject

Jouitteau suggests that this is a result of the fact that the initial element in these utterances derives from the immediate postverbal position; in other words, the element that would have appeared immediately following the verb is the one to be fronted when no element is focused. The reason that two possibilities, S-initial and Vnfin-initial, result is that there appears to be some sort of optionality regarding the element to appear in this immediate postverbal position. It can be the subject, but it may equally be the non-finite lexical verb (Jouitteau 2007: 176). As a result, both the utterances in example (11) are grammatical. This is supported by evidence from Kervella (1947), who shows that there is variability regarding the placement of the subject and non-finite verb following a finite auxiliary, as shown in example (12).

a. Subject-initial

Manon he deus kuzh -et ar c'hazh

Manon 3SG.F have.3SG.F hide -PP DET cat

'Manon has hidden the cat.'

b. Vnfin-initial

kuzh -et he deus Manon ar c'hazh

hide -PP 3SG.F have.3SG.F Manon DET cat

'Manon has hidden the cat.'

Jouitteau (2007: 176) 
a. dec'h en devoa ar merour gwerzh -et leue e yesterday 3SG.M have.PST.3SG.M DET farmer sell -PP calf his vuoc'h ruz cow red

'Yesterday the farmer had sold the calf of his red cow.'

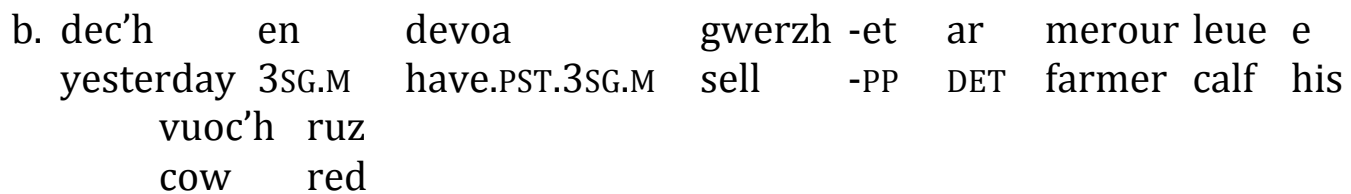

'Yesterday the farmer had sold the calf of his red cow.' Kervella (1947: 373)

The type of subject in question seems to be relevant in the variation here: since Breton is a pro-drop language, pronominal subjects need not be expressed, and so in this case the verbal noun naturally appears in the immediate postverbal position. Le Roux (1957) in fact documents that Vnfin-initial order is more common with pronominal subjects, while S-initial word order is more common with a full noun phrase. Under this view, then Breton is not shifting to a generalised SVO word order; rather, S-initial order is an alternative neutral word order, usually when the subject is not pronominal.

Further support for this explanation comes from Kennard (2014), who, as mentioned above, examines the same issues surrounding Breton word order, but in negative utterances. Since in negative utterances the negative particle can appear in initial position, this results in two main word order patterns with either the subject or the negative particle in initial position.

Negative word order

a. S-initial

$\begin{array}{llll}\text { me ne } & \text { gomz-an ket } & \text { galleg } \\ \text { I NEG } & \text { speak-1SG NEG } & \text { French } \\ \text { 'I do not speak French.' } & \end{array}$

b. NEG-initial

ne gomz-an ket galleg

NEG speak-1SG NEG French

'I do not speak French.'

The negative particle thus differs from the other preverbal particles in that it can, but need not, satisfy the V2 constraint: it is a C head, while $a$ and $e$ are not (Anderson 2005, Tallerman 2005). Following Jouitteau's (2005, 2010a) account, the preverbal particles $a$ and $e$ appear in $\mathrm{Fin}^{0}$, while the negative particle appears higher up in the left periphery. ${ }^{11}$ If Breton were shifting to S-initial word order more generally, we would expect to see S-initial word

\footnotetext{
${ }^{11}$ Note that this is not the only possible analysis of the negative particle, and of word order, in negative utterances. It is also possible to assume that the V2 constraint does not apply in negative utterances, which allows the negative particle to be treated in the same way as the other preverbal particles (e.g. Borsley \& Kathol 2000). Under this view negative utterances with initial ne would be Vfin-initial, the particle forming a single unit with the verb. This has also been claimed for Middle Welsh (Willis 1998, Meelen 2016), where the word order facts are similar. The choice between these two approaches is not crucial to the discussion in this paper.
} 
order dominating in negative utterances, with very little NEG-initial word order. In fact, the study finds that this is not the case: all speakers use NEG-initial word order in at least some utterances, and it is overall the preferred word order with pronominal subjects.

In addition, there is evidence that regional variation may play a role in Breton word order. Avézard-Roger (2004) finds that dialects from different parts of Brittany show variation regarding the most frequent word order, with speakers from the south-west using Sinitial word order much more frequently than speakers from the central region, where the most frequent construction places the non-finite verb in initial position. This suggests that individual speakers may prefer one neutral construction over another, but that a generalisation for Breton as a whole might be more difficult to arrive at.

\subsection{Word order in Neo-Breton}

As has already been mentioned above, Neo-Breton has been identified as differing from the traditional Breton of native speakers. The question therefore arises as to how these new speakers of Breton use word order. Varin (1979) was again the first to address this issue, contrasting traditional Breton with what she terms 'brezhoneg chimik', or 'chemical Breton'; namely, the newly-created standard language. She writes that traditional Breton is SVO, as discussed above, but that these SVO patterns are not used in brezhoneg chimik.

While Varin discusses 'speakers' of Breton, her data come from written sources, and might therefore not reflect actual usage in speech. It appears that there are two opposing tendencies in Neo-Breton: the first is to generalise subject-initial word order under influence from French, since Neo-Breton speakers tend to come from a French-speaking background, are consequently native speakers of French, and may therefore be French-dominant (McDonald 1989). Neo-Breton speakers are, however, aware of this potential for overuse of the subject-initial pattern, and as Avézard-Roger (2004) writes, S-initial word order has become stigmatised among younger speakers because it is perceived to be 'too French'. As a result, there is a counter tendency in Neo-Breton to avoid S-initial word order due to this stigmatisation, which results in underuse of the S-initial pattern, even when it would be appropriate in traditional Breton (German 2007).

Kennard's (2014) study of negative word order finds that there is a greater preference for S-initial word order among older traditional speakers, which is not shared by Neo-Breton speakers. Having said that, all speakers seem to prefer subject-initial word order with nonpronominal subjects. Avézard-Roger (2004) also notes that there is a loss of regional variation in Neo-Breton, which is unsurprising given its status as a pan-dialectal standard variety. With this background in mind, the next question is how speakers from different generations use word order in non-negative utterances, which are arguably more representative of 'basic' word order, and which might shed further light on recent developments in Breton syntax, and how the tendencies for and against S-initial word order might interact. 


\section{FIELDWORK METHODOLOGY}

To explore the questions raised by considering the literature on Breton and Neo-Breton, fieldwork was undertaken in southwest Brittany. Two visits were made, the first in March 2010 and the second in October 2011. The location chosen was the city of Quimper, in southern Finistère, and the surrounding small towns and villages. This is the heart of the kerneveg dialect region, and has received somewhat less attention in the literature than the other dialects; Jackson writes in his seminal work on historical phonology and morphology that 'Cornouaille Breton has been wholly ignored... since scarcely any sort of treatment of any dialect in modern phonetic terms is known... and it has no pretensions to be regarded as a literary language; and in addition the sub-dialects differ so very greatly among themselves' (Jackson 1967: 37). More recent work has redressed this balance somewhat (see, e.g. Denis 1977, Dressler \& Hufgard 1980), but kerneveg remains understudied.

\subsection{Speakers}

The goal of the fieldwork was to interview both traditional and new speakers of Breton, and compare their use of word order. In total, eight older native speakers were interviewed, all of whom had acquired Breton in the home as a native language, and most of whom spoke no French before they went to school, aged about 6 . These speakers, denoted by the letters G, J, K, $\mathrm{M}, \mathrm{N}, \mathrm{QN}, \mathrm{V}$ and $\mathrm{X}$, were aged between 60 and 90 at the time of the fieldwork, and had all lived in rural locations or small villages throughout their lives. This group is termed senior adults in the discussion.

To examine the younger generation of new Breton speakers, two groups were interviewed. The first were the young adults: speakers aged 20-40 who had acquired Breton through education, as well as through further study and interaction with older Breton speakers. Although they came from French-speaking homes, and did not consider themselves to be native speakers of Breton, all were employed in jobs where they used Breton on a daily basis with colleagues and the public. Nine young adults were interviewed, and they are denoted by the letters C, D, E, H, I, L, O, TX and VY.

The second group of new speakers was formed of children aged 8-15 who were in Breton-medium education at the time of the fieldwork. None of them came from Bretonspeaking homes, and they were consequently French-dominant. Three, A, B and T, attended a Diwan school, and were interviewed on both fieldwork visits. The other thirteen, AJ, BK, CG, EL, F, FM, P, R, S, U, W, Y and Z, were interviewed only once, on either the first or the second visit, and there is consequently less data for each of these speakers individually.

\subsection{Elicitation}

The aim was to elicit utterances across a range of constructions in as neutral a context as possible. To avoid potential influence from French (as far as feasible), it was decided that translation would be an unsuitable method of elicitation, since it encourages speakers to translate sentences, if not exactly word-for-word, then preserving the word order of the original. Indeed, older speakers recall that when they were young, it was not unusual to hear 
Breton-dominant speakers producing utterances in French with Breton word order, and Le Dû (2011) takes a humourous look at examples of this, such as 'du café vous aurez'.

Rather than using translation, then, two alternative methods of elicitation were used. In the first, speakers were presented with photographs and short films (5-10 seconds) of people or animals performing actions, and were asked to say, in Breton, what was happening. It was hoped that this would elicit all-focus utterances without any particular focused constituent. For example, speakers might be shown a photograph such as that in Figure 1, which shows a man eating something, and the expected response would be 'The man is eating some bread/a sandwich/something'. This method was particularly useful for eliciting progressive utterances: speakers are prompted to describe what is happening, although some speakers did produce non-progressive utterances, particularly of the type 'the man likes the bread', using stative verbs.

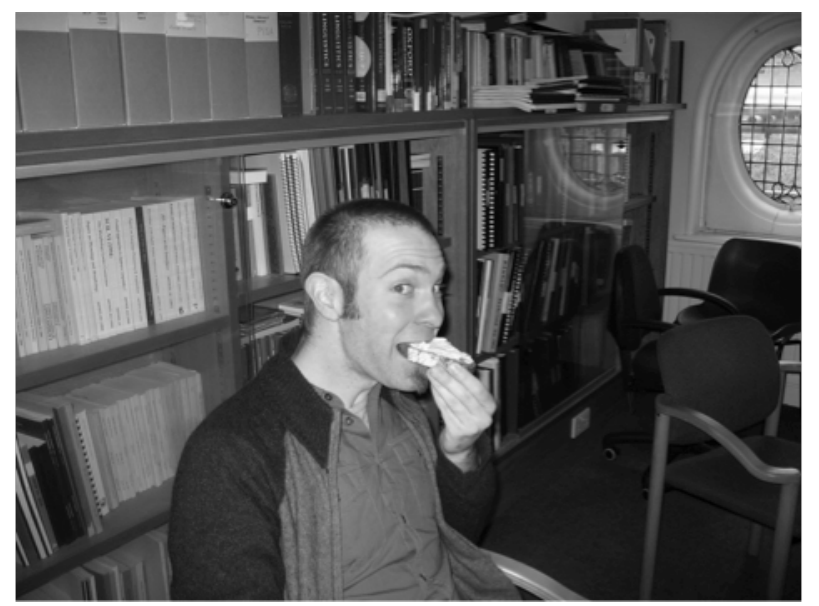

Figure 1: Photographic fieldwork prompt

Additionally, some speakers had a tendency to produce non-finite descriptive utterances such as 'a man eating some bread', which were obviously unusable in the present study. The incorporation of short films largely solved this problem, as speakers were more willing to produce finite, complete utterances in response to these.

While the use of photographs did elicit some non-progressive utterances, another method was employed to elicit the bulk of these. Participants were given word cards with Breton nouns and verbs, and asked to form sentences from them, filling in whatever was necessary to make the sentence grammatical (e.g. using articles, conjugating the verb, etc.). For example, a speaker might be given cards with the words klevout 'to hear', mamm-gozh 'grandmother' and $k i$ 'dog', with the expected response being similar to those given in (10).

(14) Possible responses to word card task

a. Subject-initial

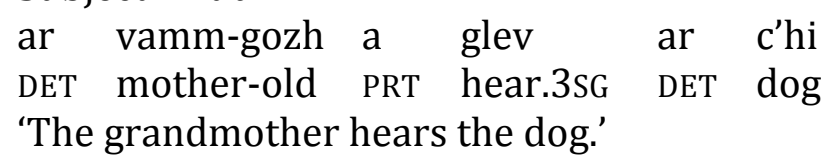


b. Vnfin-initial

$\begin{array}{lllll}\text { klevout a ra } & \text { ar } & \text { vamm-gozh } & \text { ar } & \text { c'hi } \\ \text { hear.VN PRT } & \text { do.3SG } & \text { DET mother-old } & \text { DET } & \text { dog } \\ \text { 'The grandmother hears the dog.' } & \end{array}$

The cards were placed on the table in front of the speakers in no particular order, to avoid, for example, always presenting the verb first and thereby suggesting a verb-initial word order. As there was no preceding context, it was hoped that this would also result in an all-focus utterance. The use of written Breton brought its own difficulties: while the younger generation are able to read and write Breton proficiently, the same is not true of the senior adults. All of them attended school at a time when only French was used, and most of them had never learnt to read or write Breton, although they had all seen Breton written in signage or local newspapers, etc. With this in mind, efforts were made to choose frequently-used words that would be familiar to older speakers, and most of them managed the task well. The biggest challenge for them was to identify the words from their potentially unfamiliar spelling, but once they had achieved this, forming an utterance using the words was relatively straightforward.

\subsection{Analysis of the data}

All of the speakers were audio-recorded, and the data analysed afterwards. Each utterance was categorised according to its word order pattern. For non-progressive utterances, these categories comprised 'S-initial', 'Vnfin-initial', and 'Other', which included any utterance that did not fit into one of the main word order patterns. On the whole, there were relatively few of these utterances, suggesting that speakers were not fronting focused constituents, and thereby producing utterances with narrow focus on some element, such as the object. They usually arose because a speaker began the utterance with an adverb such as amañ 'here', or setu 'here is' (cf. French voilà). Examples are given in (15).

\section{'Other' word order patterns}

a. amañ [e] teu ar pichon da glask ar boued here [PRT] come.3SG DET pigeon to seek.VN DET food 'Here comes the pigeon to seek the food.' Speaker $K$

b. setu se blij deont here DEM please.3SG to.3PL 'Here they like that.'

Speaker $C$

For progressive utterances, the main word order categories were 'S-initial' and 'Vfininitial', where the auxiliary is in initial position. Again, there were some utterances which displayed neither of these patterns. Examining these exceptions, it was decided to include the category 'Vnfin-initial' once again, as it became clear that this was a significant pattern for some speakers. The remaining exceptions were grouped under 'Other', and like the nonprogressive utterances, mostly had an adverb in initial position. One of the children, BK, also produced utterances beginning with the dummy element bez', and an example is given in (16). Initial bez' or bezañ is an inert particle derived from the verb 'to be', which is used as a solution to the V2 constraint: it allows the speaker to fill the initial position without fronting a 
constituent. It is sometimes considered to have a completely pragmatically neutral reading, but research into variation in Breton syntax (Jouitteau 2017) indicates in some contexts, bez' produces emphasis on the verb.

$$
\begin{aligned}
& \text { Initial bez' } \\
& \text { bez' zo ur plac'h o serriñ an nor } \\
& \text { BEZ be.UNIN DET girl PRT close.VN DET door } \\
& \text { 'The girl is closing the door.' }
\end{aligned}
$$

Speaker BK

Given that use of bez' was not found more widely in the data, and it is more commonly used in northern dialects, the decision was made not to treat these utterances as a separate category. The next section examines the findings from the fieldwork data.

\section{FINDINGS}

\subsection{Non-progressive utterances}

Beginning with non-progressive utterances, it is immediately clear that the type of subject speakers use has an impact on the word order they select; that is, the word order patterns are different for utterances where the subject is a pronoun from those where the subject is a noun. These subject types are here termed pronominal and lexical subjects respectively, and the difference between them can be seen in Table 1 .

Table 1: Pronominal vs. lexical subjects in non-progressive utterances (raw numbers and percentages)

\begin{tabular}{lllllll}
\hline Subject type & S-initial & \multicolumn{3}{l}{ Vnfin-initial } & Other \\
\hline Lexical & 105 & $71.9 \%$ & 35 & $24.0 \%$ & 6 & $4.1 \%$ \\
Pronominal & 89 & $47.6 \%$ & 88 & $47.1 \%$ & 10 & $5.3 \%$ \\
\hline
\end{tabular}

Speakers use subject-initial word order in a greater proportion of utterances with lexical subjects than with pronominal subjects, where subject-initial and verbal noun initial word orders are used almost equally. A chi-squared test of independence shows the difference between these types of utterance to be statistically significant $\left(\mathrm{X}^{2}=20.4, \mathrm{df}=2, \mathrm{p}<\right.$ 0.001). It therefore seems sensible to examine these different types of subject separately.

Looking first at utterances with a lexical subject, as in Table 2, we can observe the

\begin{tabular}{|c|c|c|c|c|c|c|}
\hline & $S$-initial & & Vnfin-initia & & Other & \\
\hline$S A$ & 23 & $92 \%$ & 1 & $4 \%$ & 1 & $4 \%$ \\
\hline$Y A$ & 29 & $69.1 \%$ & 11 & $26.2 \%$ & 2 & $4.8 \%$ \\
\hline Children & 53 & $59.6 \%$ & 23 & $25.8 \%$ & 3 & $3.4 \%$ \\
\hline
\end{tabular}
following:

Table 2: Word order usage in non-progressive utterances with a lexical subject (raw numbers, with percentages)

The table indicates that the senior adults have a strong preference for subject-initial word order, as would be expected for lexical subjects. Vnfin-initial word order is very rare 
among these speakers; the single example from the data is given in (17b). The younger generation, both adults and children, also prefer subject-initial word order, but for them, Vnfin-initial word order is also a lesser-used alternative, as in (18).

\section{(17) Senior adults}

a. S-initial

div vaouez [a] sell d' ar foto-ioù

two.F woman [PRT] look at DET photograph-PL

'Two women look at the photos.'

Speaker $K$

b. Vnfin-initial [single example]

c'hoarzhin a reont an div vaouez

laugh.VN PRT do.3PL DET two.F woman

'The two women laugh.'

Speaker J

(18) Young adults

a. S-initial

ar vugale a bren aval-où

DET children PRT buy.3SG apple-PL

'The children buy apples.'

Speaker E

b. Vnfin-initial

lammat a ra ar paotr-mañ

jump.VN PRT do.3SG DET boy-DEM

'This boy jumps.'

Speaker I

As some of the cell values are very small $(<5)$, a chi-squared test would not be appropriate here, and instead a Fisher's Exact Test was used; however, the proportion of Sinitial and Vnfin-initial utterances does not differ significantly across the generations $(\mathrm{p}=$ 0.067). This may be because the sample size for the senior adults is quite small. We can therefore observe only a tendency in the data.

Looking now at utterances with a pronominal subject, a slightly different pattern emerges (see Table 3).

Table 3: Word order usage in non-progressive utterances with a pronominal subject (raw numbers, with percentages)

\begin{tabular}{lllllll}
\hline & S-initial & \multicolumn{3}{c}{ Vnfin-initial } & Other & \\
\hline$S A$ & 19 & $59.4 \%$ & 11 & $34.4 \%$ & 2 & $6.3 \%$ \\
$Y A$ & 20 & $37.7 \%$ & 25 & $47.2 \%$ & 8 & $15.1 \%$ \\
Children & 50 & $49.0 \%$ & 52 & $51.0 \%$ & 0 & $0 \%$ \\
\hline
\end{tabular}

Here, S-initial word order is still preferred by the senior adults, which is quite striking given that there is no need to use an overt pronoun in Breton - the senior adults are therefore choosing to insert one in more than half of utterances. However, they do also use Vnfin-initial word order (see (15)). The younger generation also use S-initial word order, but they use Vnfin-initial word order in a much greater proportion of utterances than the senior adults. 
The children use both word order patterns in roughly equal proportions, while the young adults use Vnfin-initial word order more than S-initial word order.

(19) Senior adults

a. S-initial

$\begin{array}{llll}\text { eñ } \quad[\mathrm{a}] \quad \text { zigor } & \text { an } & \text { nor } \\ \text { he [PRT] open.3SG } & \text { DET } & \text { door } \\ \text { 'He opens the door.' } & \end{array}$

Speaker $V$

b. Vnfin-initial

debriñ a reont

eat.VN PRT do.3PL

'They eat.'

Speaker $K$

(20) Young adults

a. S-initial

$\begin{array}{llllll}\text { me } \quad[\mathrm{a}] \text { soñj } & \text { eo } & \text { ar } & \text { plac'h } & \text { laouen } \\ \text { I } & \text { [PRT] think.3SG } & \text { be.3SG } & \text { DET } & \text { girl } & \text { happy } \\ \text { 'I think that the girl is happy.' } & & \end{array}$

Speaker $H$

b. Vnfin-initial

gwelout a ran un tad hag e baotr-ed
see.VN PRT do.1SG DET father and his boy-PL
'I see a father and his boys.'

'I see a father and his boys.'

Speaker $L$

Using Fisher's Exact Test, we can see that the difference between the generations is statistically significant $(p=0.003)$, unlike in utterances with a lexical subject. However, this result is less useful than it might at first appear: since this is a $3 \times 3$ table, further tests are required to identify what exactly is giving this significant result; that is, between which groups, and in which types of utterance. This can be achieved by running further Fisher's Exact Tests on $2 \times 2$ subsets of the data, and then applying the Bonferroni correction to account for running multiple tests on the same data. ${ }^{12}$ There are nine possible $2 \times 2$ comparisons to be drawn from the above data, covering the different combinations of speaker group and word order pattern. These are presented in Table 4 below, together with the p-value arising from each Fisher's Exact Test.

Table 4: Post-hoc comparisons of non-progressive utterances with a pronominal subject

\begin{tabular}{lll}
\hline Group comparison & Word order comparison & p-value \\
\hline SA x YA & S-initial x Vnfin-initial & 0.156947 \\
SA x Children & S-initial x Vnfin-initial & 0.213234 \\
YA x Children & S-initial x Vnfin-initial & 0.720452 \\
SA x YA & S-initial x Other & 0.155431 \\
SA x Children & S-initial x Other & 0.084507 \\
YA x Children & S-initial x Other & 0.000133 \\
SA x YA & Vnfin-initial x Other & 0.70027 \\
SA x Children & Vnfin-initial x Other & 0.0375 \\
YA x Children & Vnfin-initial x Other & 0.000289 \\
\hline
\end{tabular}

12 This technique is suggested by McDonald (2014: 77-85). 
A number of comparisons have a p-value lower than 0.05 , which gives an indication of what is driving the significant result above. However, the Bonferroni correction means that the usual significance threshold must be divided by the number of tests, namely 9 , giving a significance threshold of 0.006 . This means that the significant result is being driven by the difference between the young adults and children in utterances where the initial constituent is categorised as 'other'. Recall that these utterances have a constituent other than the subject or the non-finite verb in initial position, which might be the object, an adverbial, or a null element such as bez'. The young adults produced a greater proportion of 'other' utterances in this context than might be expected, and some examples are given in (21).

(21) Other

a. Senior adults

amañ a ya pourmen

here PRT go.3SG walk.VN

'Here he goes for a walk.'

Speaker $X$

b. Young adults

daou -lagad brav he deus

DU -eyes nice 3SG.F have.3SG.F

'She has nice eyes.'

Speaker $O$

If these 'other' utterances are omitted from the analysis, there is no longer a significant result $\left(X^{2}=2.72, d f=2, p=0.25\right)$. Again, we can observe a tendency in the data for the senior adults to prefer S-initial word order, but the difference between the generations is too small to be significant. This may again be due to the small sample size.

\subsection{Progressive utterances}

Turning now to progressive utterances, similar patterns can be observed. Recall that in progressive utterances, an additional word order pattern is available to speakers, placing the finite auxiliary emañ (and its various forms) in initial position. Speakers can equally use subject-initial word order, or place the verbal noun (with the progressive particle) in initial position as a non-finite verb. Note, however, that although this appears to be the same as the Vnfin-initial word order used in non-progressive utterances, in fact it is not an exact equivalent. Progressive utterances with an initial non-finite verb actually have both the verb and the object, if there is one, in the preverbal position. Examples are given in (22). In the data that are presented below, the label Vnfin-initial is retained for simplicity, but the implications of this contrast between progressive and non-progressive Vnfin-initial utterances will be discussed in more detail in section 5.

Progressive utterances

a. Subject-initial

$\begin{array}{lllllll}\text { ar plac'h } & \text { a } & \text { zo } & \text { o } & \text { lenn } & \text { ul } & \text { levr } \\ \text { DET girl } & \text { PRT } & \text { be.UNIN } & \text { PRT } & \text { read.PROG } & \text { DET } & \text { book } \\ \text { 'The girl is reading a book.' } & & & \end{array}$


b. Vfin-initial

emañ ar plac'h o lenn ul levr

be.SIT.3SG DET girl PRT read.PROG DET book

'The girl is reading a book.'

c. Vnfin(+NP)-initial

o lenn ul levr emañ ar plac'h

PRT read.PROG DET book be.SIT.3SG DET girl

'The girl is reading a book.'

In light of the contrast that was found in non-progressive utterances between those with a lexical subject and those with a pronominal subject, it seems sensible to look at progressive utterances in the same way. As Table 5 shows, speakers do seem to treat the different types of subject differently in progressive utterances as well, with a greater preference for subject-initial word order with lexical subjects, and a greater preference for Vfin-initial order with pronominal subjects. A chi-squared test shows this to be a significant difference $\left(X^{2}=245.07, d f=3, p<0.001\right)$.

Table 5: Pronominal vs. lexical subjects in progressive utterances

\begin{tabular}{lllllllll}
\hline Subject type & \multicolumn{2}{l}{ S-initial } & \multicolumn{2}{l}{ Vfin-initial } & \multicolumn{2}{l}{ Vnfin-initial } & \multicolumn{2}{l}{ Other } \\
\hline Lexical & 290 & $77.1 \%$ & 16 & $4.2 \%$ & 45 & $12.0 \%$ & 25 & $6.6 \%$ \\
Pronominal & 33 & $20.9 \%$ & 102 & $64.6 \%$ & 10 & $6.3 \%$ & 13 & $8.2 \%$ \\
\hline
\end{tabular}

It is clear that in utterances with a lexical subject, subject-initial word order is preferred, and as the data in Table 6 show, this is particularly true for the senior adults. This is not surprising, given the findings for non-progressive utterances. The groups in the younger generation also use a high proportion of subject-initial word order, but they use Vnfin-initial word order in addition, which is not used at all by the senior adults.

Table 6: Word order usage in progressive utterances with a lexical subject (raw numbers and percentages)

\begin{tabular}{lllllllll}
\hline & S-initial & \multicolumn{2}{l}{ Vfin-initial } & \multicolumn{2}{l}{ Vnfin-initial } & \multicolumn{2}{l}{ Other } \\
\hline$S A$ & 35 & $85.3 \%$ & 3 & $7.3 \%$ & 0 & $0 \%$ & 3 & $7.3 \%$ \\
$Y A$ & 58 & $70.7 \%$ & 5 & $6.1 \%$ & 17 & $20.7 \%$ & 2 & $2.4 \%$ \\
Children & 197 & $77.9 \%$ & 8 & $3.2 \%$ & 28 & $11.1 \%$ & 20 & $7.9 \%$ \\
\hline
\end{tabular}

(23) Senior adults

a. Subject-initial

an tud zo [o] tañsal

DET people be.UNIN [PRT] dance.PROG

'The people are dancing.'

Speaker V

b. Vfin-initial

emañ daou o selaou

be.SIT.3SG two.M PRT listen.PROG

'Two (of them) are listening.'

Speaker K 
(24) Young adults

a. Subject-initial

div vaouez a zo o tiskenn an diri

two.F woman PRT be.UNIN PRT descend.PROG DET staircase

'Two women are going down the stairs.'

Speaker $E$

b. Vfin-initial

emañ ar paotr o c'hortoz an tren

be.SIT.3SG DET boy PRT wait.for.PROG DET train

'The boy is waiting for the train.'

Speaker O

c. Vnfin-initial

o prenañ boued emañ ar paotr

PRT buy.PROG food be.SIT.3SG DET boy

'The boy is buying food.'

Speaker VY

(25) Children

a. Subject-initial

daou vaouez a zo o c'hoarzhin

two.M woman PRT be.UNIN PRT laugh.PROG

'Two women are laughing.'13

Speaker A

b. Vfin-initial

emañ ar babig o mousc'hoarzhin

be.SIT.3SG DET baby PRT smile.PROG

'The baby is smiling.' 14

Speaker B

c. Vnfin-initial

o evañ emañ ar paotr-se

PRT drink.PROG be.SIT.3SG DET boy-DEM

'That boy is drinking.'

Speaker $U$

A Fisher's Exact Test on the data in Table 6 (minus the 'Other' category, which is less relevant, and led to confusion in non-progressive utterances) shows that the differences between the speaker groups are significant $(\mathrm{p}=0.003)$. Again, further post-hoc tests are required to identify what is driving this significant result. The results of the nine possible $2 x 2$ comparisons are presented in Table 7.

\footnotetext{
${ }^{13}$ Here, Speaker A uses the masculine daou 'two' with a feminine noun - this mismatch of gender is relatively common in the children's data [expected: div vaouez].

${ }^{14}$ Speaker B here omits the expected mixed mutation on the verb following the progressive particle [expected: $o$ vousc'hoarzhin].
} 
Table 7: Post-hoc comparisons of progressive utterances with a lexical subject

\begin{tabular}{lll}
\hline Group comparison & Word order comparison & p-value \\
\hline SA x YA & S x Vfin & 1 \\
SA x Children & S x Vfin & 0.385363 \\
YA x Children & S x Vfin & 0.19277 \\
SA x YA & S x Vnfin & 0.001193 \\
SA x Children & S x Vnfin & 0.019253 \\
YA x Children & S x Vnfin & 0.039832 \\
SA x YA & Vfin x Vnfin & 0.024348 \\
SA x Children & Vfin x Vnfin & 0.018054 \\
YA x Children & Vfin x Vnfin & 1 \\
\hline
\end{tabular}

While a number of comparisons have a p-value lower than 0.05 (pale shading in Table 7), the Bonferroni correction must again be applied, giving a significance threshold of 0.006 . As a result, only the comparison of senior adults and young adults across subject-initial and Vnfin-initial word order is statistically significant in this context (dark shading in Table 7). What this tells us, then, is that it is the use of Vnfin-initial order with respect to other word order patterns that is particularly salient in distinguishing between the different groups of speakers.

Looking at little more closely at the data provides additional information about word order usage. As the data above might suggest, word order usage across the senior adults is fairly consistent, with most speakers using only subject-initial word order. There are only 6 exceptions to this - three Vfin-initial utterances, all by speaker K, and 3 utterances in the category 'other', used by speakers J and X (see Figure 2).

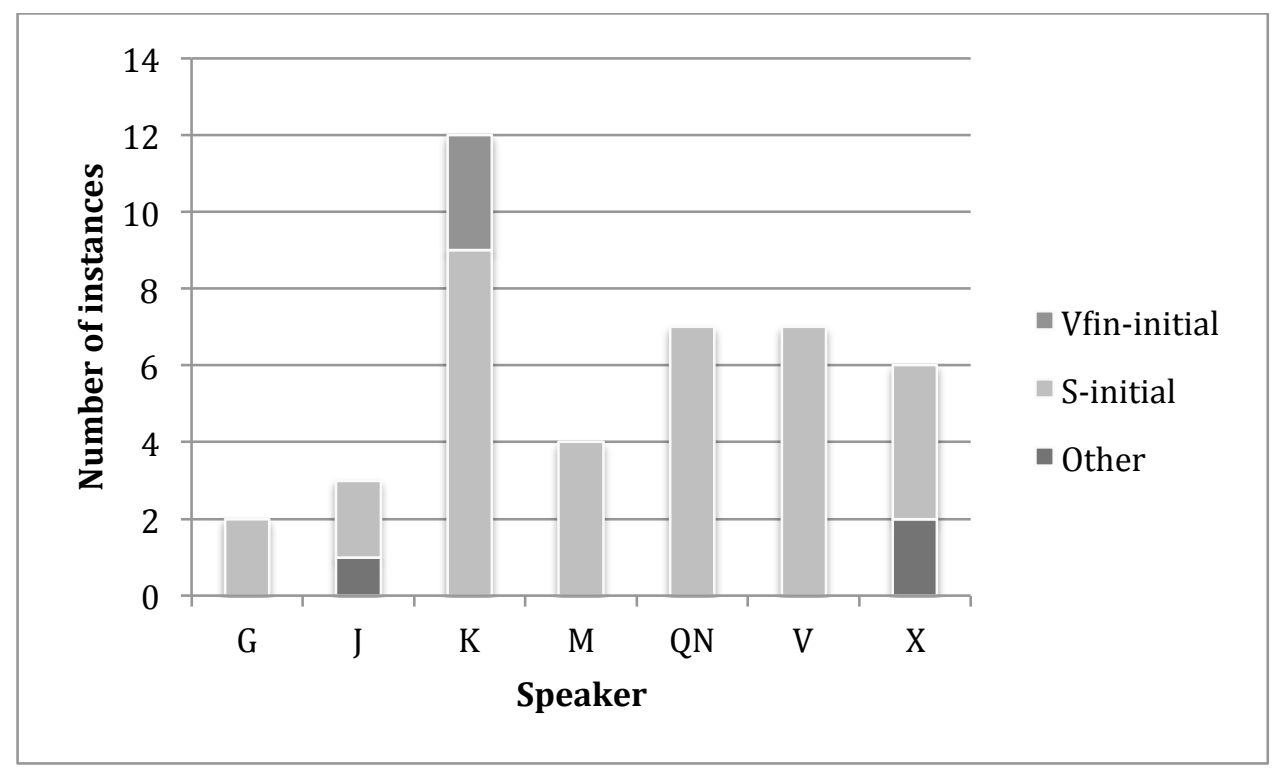

Figure 2: Progressive utterances with a lexical subject: senior adults, by speaker

The pattern for the young adults is quite different, because here there is much more interspeaker variation. As Figure 2 shows, the 17 instances of Vnfin-initial word order are concentrated in just two speakers, E and VY. While they make up only $30 \%$ of E's utterances, VY uses exclusively this word order pattern in progressive utterances with a lexical subject. 
Vfin-initial word order is also confined to just three speakers, but there is not the same contrast between the generations with regard to this word order pattern, in contrast with Vnfin-initial utterances which are simply not found in the older generation's data. Two speakers are therefore heavily influencing the profile of the young adults as a group. Variation among the children will be discussed below.

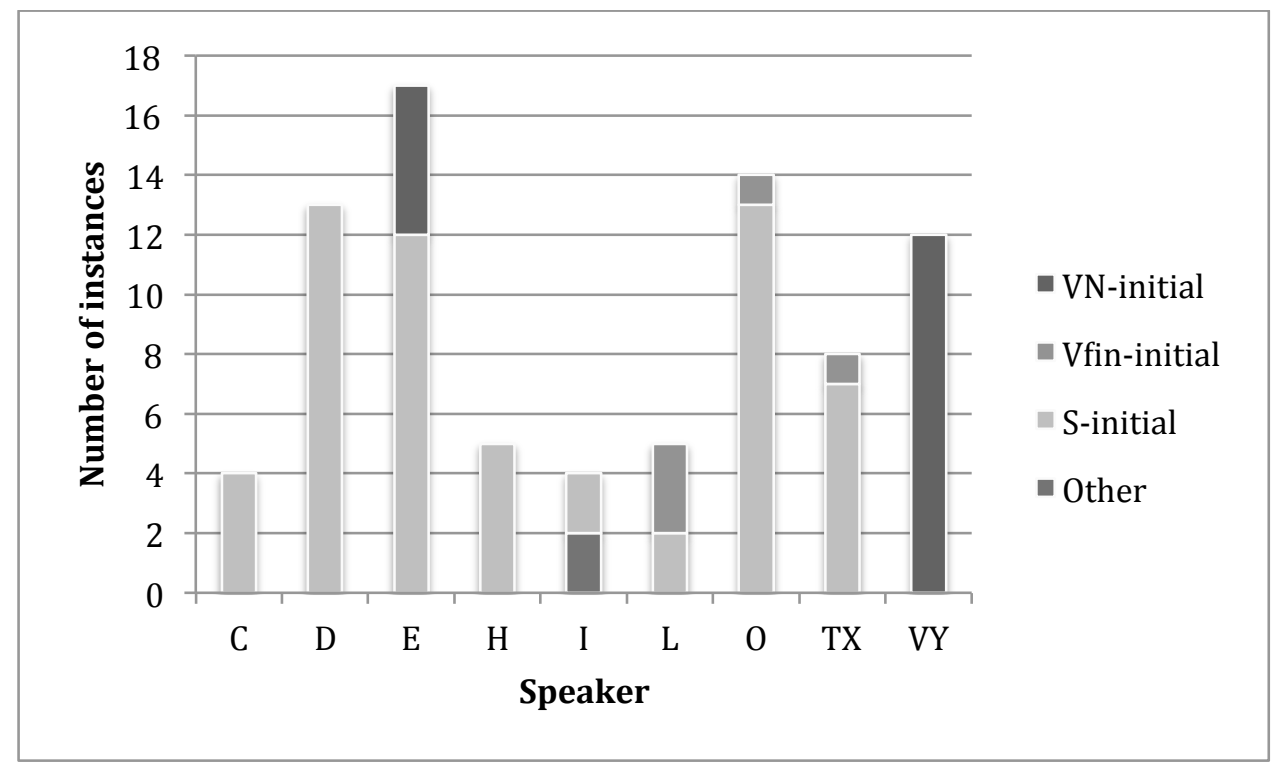

Figure 3: Progressive utterances with a lexical subject: young adults by speaker (raw numbers)

Turning now to progressive utterances with a pronominal subject, quite a different pattern emerges. As we saw earlier, Vfin-initial word order is much more frequently used in these utterances, and is the dominant word order pattern. The senior adults also use subjectinitial word order in just over a quarter of their utterances, which is consistent with their word order usage generally. The data for the children are a little more limited, but they seem to indicate that the Vnfin-initial pattern is also relatively frequently used for these speakers.

Table 8: Progressive utterances with a pronominal subject (raw numbers and percentages)

\begin{tabular}{lllllllll}
\hline & \multicolumn{2}{l}{ S-initial } & \multicolumn{2}{l}{ Vfin-initial } & \multicolumn{2}{c}{ Vnfin-initial } & \multicolumn{2}{l}{ Other } \\
\hline$S A$ & 24 & $26.6 \%$ & 51 & $56.6 \%$ & 4 & $4.4 \%$ & 11 & $12.2 \%$ \\
$Y A$ & 5 & $10.6 \%$ & 39 & $82.9 \%$ & 1 & $2.1 \%$ & 2 & $4.2 \%$ \\
Children & 4 & $19.0 \%$ & 12 & $57.1 \%$ & 5 & $23.8 \%$ & 0 & $0 \%$ \\
\hline
\end{tabular}

(26) Senior adults

a. Vfin-initial

emaint [o] tiskutal

be.SIT.3PL [PRT] discuss.PROG

'They are discussing (something).'

Speaker K

b. S-initial
hi zo brodañ
she be.UNIN embroider.PROG
'She is embroidering.'

Speaker QN 
c. Vnfin-initial

$\mathrm{e}^{15} \quad$ lenn emañ

PRT read.PROG be.SIT.3SG

'He/she is reading.'

Speaker $N$

(27) Children

a. Vfin-initial

emañ o zebriñ ur gwastell vras $^{16}$

be.SIT.3SG PRT eat.PROG DET cake big

'He/she is eating a big cake.'

Speaker BK

b. S-initial

hi zo o sav ${ }^{17}$ an dorn

she be.UNIN PRT raise DET hand

'She is raising her hand.'

Speaker $C G$

c. Vnfin-initial

o neuial emaint

PRT swim.PROG be.SIT.3PL

'They are swimming.'

Speaker B

A Fisher's Exact Test indicates that there are significant differences between the generations $(p=0.003)$. Again, to determine where the interesting contrasts lie, a number of post-hoc tests must be performed. Table 9 gives the results of these tests.

Table 9: Post-hoc comparisons of progressive utterances with a lexical subject

\begin{tabular}{lll}
\hline Group comparison & Word order comparison & p-value \\
\hline SA x YA & S x Vfin & 0.014389 \\
SA x Children & S x Vfin & 0.767645 \\
YA x Children & S x Vfin & 0.229713 \\
SA x YA & S x Vnfin & 1 \\
SA x Children & S x Vnfin & 0.023061 \\
YA x Children & S x Vnfin & 0.286713 \\
SA x YA & Vfin x Vnfin & 0.393601 \\
SA x Children & Vfin x Vnfin & 0.132658 \\
YA x Children & Vfin x Vnfin & 0.007162 \\
\hline
\end{tabular}

There are three significant results, across the different groups and word order types (light shading in Table 9), which does little to clarify the picture. However, after the Bonferroni correction, none of these are statistically significant. This is probably due to the small sample sizes among the younger generation, and in particular the children. However, the general tendency for the senior adults to use subject-initial word order in a greater

\footnotetext{
15 Speaker $\mathrm{N}$ uses the $e$ variant of the progressive particle, rather than $o$.

16 Here, Speaker BK uses lenition in place of the mixed mutation on the verb (expected: $o$ tebriñ), but fails to lenite the feminine noun gwastell following the article (expected: ur wastell), although the following adjective is mutated. This is very common in the children's Breton (for more discussion of children's use of mutation, see Kennard \& Lahiri (2017) and Kennard (2018)).

${ }^{17}$ Speaker CG uses the radical, or stem form, of the verb here, rather than the verbal noun (expected: sevel).
} 
proportion of utterances is maintained, as is the preference for placing the finite element in initial position where possible.

Finally, we can look at the different groups of children, to examine whether the type of schooling they receive is having an impact on their word order usage. In non-progressive utterances, it seems not: the children use word order patterns in much the same way regardless of which type of schooling they receive, and this is true of both lexical and pronominal subjects. A chi-squared test run on each type of utterance returns a nonsignificant result (lexical: $\mathrm{X}^{2}=0.18, \mathrm{df}=1, \mathrm{p}=0.67$; pronominal: $\mathrm{X}^{2}=0.12, \mathrm{df}=1, \mathrm{p}=0.7281$ ).

Table 10: Non-progressive utterances with a lexical subject - schooling comparison

\begin{tabular}{lllllll}
\hline Schooling & S-initial & \multicolumn{4}{l}{ Vnfin-initial } & Other \\
\hline DivYezh & 35 & $67.3 \%$ & 14 & $26.9 \%$ & 3 & $5.8 \%$ \\
Diwan & 18 & $66.7 \%$ & 9 & $33.3 \%$ & 0 & $0 \%$ \\
\hline
\end{tabular}

Table 11: Non-progressive utterances with a pronominal subject - schooling comparison

\begin{tabular}{lllllll}
\hline Schooling & S-initial & \multicolumn{4}{l}{ Vnfin-initial } & Other \\
\hline DivYezh & 39 & $50.6 \%$ & 38 & $49.4 \%$ & 0 & $0 \%$ \\
Diwan & 11 & $44 \%$ & 14 & $56 \%$ & 0 & $0 \%$ \\
\hline
\end{tabular}

In progressive utterances, however, the findings are more interesting. As Table 12 shows, children who attend a Diwan school use Vfin-initial and Vnfin-initial word order in a greater proportion of utterances with a lexical subject than children who attend DivYezh classes. A Fisher's Exact Test shows that this difference is statistically significant $(\mathrm{p}<0.001)$.

Table 12: Progressive utterances with a lexical subject - schooling comparison (raw numbers and percentages)

\begin{tabular}{lllllllll}
\hline Schooling & \multicolumn{1}{l}{ S-initial } & \multicolumn{2}{l}{ Vfin-initial } & \multicolumn{2}{l}{ Vnfin-initial } & \multicolumn{2}{l}{ Other } \\
\hline DivYezh & 146 & $84.4 \%$ & 0 & $0 \%$ & 11 & $6.4 \%$ & 16 & $9.2 \%$ \\
Diwan & 51 & $63.8 \%$ & 8 & $10 \%$ & 17 & $21.3 \%$ & 4 & $5 \%$ \\
\hline
\end{tabular}

A similar tendency can be observed in utterances with a pronominal subject (see Table 13), where the Diwan children never use subject-initial word order. Although the data are very sparse, the difference between the two groups is still statistically significant (Fisher's Exact Test: $p=0.018$ ).

Table 13: Progressive utterances with a pronominal subject - schooling comparison (raw numbers)

\begin{tabular}{lllllllll}
\hline Schooling & \multicolumn{2}{l}{ S-initial } & \multicolumn{2}{l}{ Vfin-initial } & \multicolumn{2}{c}{ Vnfin-initial } & \multicolumn{2}{c}{ Other } \\
\hline DivYezh & 4 & $50 \%$ & 3 & $37.5 \%$ & 1 & $12.5 \%$ & 0 & $0 \%$ \\
Diwan & 0 & $0 \%$ & 9 & $69.2 \%$ & 4 & $30.8 \%$ & 0 & $0 \%$ \\
\hline
\end{tabular}

It seems, then, that while the DivYezh children are using subject-initial word order more frequently in progressive utterances, the Diwan children are using Vfin-initial and Vnfininitial word order with both lexical and pronominal subjects. In a sense, the Diwan children's word order usage is more 'extreme' than that of the other children, or even the young adults. 
The DivYezh children are likely to be more influenced by French, since they are taught in both languages, and mix with French-only classes within the same school. This is reflected in their word order usage, with a greater degree of subject-initial utterances.

\section{DISCUSSION}

The findings show that speakers use word order differently depending on the type of subject in the utterance. To summarise, first of all: in both progressive and non-progressive utterances, subject-initial word order is preferred with lexical subjects, while other types of word order may be used, or even preferred, with pronominal subjects. The data also indicate that there are differences between the generations of speakers in their usage of word order. The senior adults show a general preference for subject-initial word order, not just with lexical subjects, but also to some extent with pronominal subjects. However, in progressive utterances with a pronominal subject, their dominant word order pattern places the finite auxiliary in initial position, with subject-initial word order as a secondary pattern. The younger generation of speakers, both young adults and children, are more likely to place the non-finite verb or the finite auxiliary in initial position (depending on the type of utterance), particularly in utterances with a pronominal subject. There is also more interspeaker variation amongst the younger generation: the young adults have a much higher usage of Vnfin-initial word order in progressive utterances, something that is not found at all among the senior adults, but closer inspection of the data indicates that this usage is confined to just two speakers, and in fact most of the instances come from a single speaker. Finally, there seem to be differences between the children based on the type of schooling they receive. In progressive utterances, children who attend the Diwan schools use subject-initial word order less than children who attend the DivYezh schools. However, this difference does not extend to non-progressive utterances.

A number of interesting points therefore arise. The first is the preference for subjectinitial word order among the senior adults, and the potential avoidance of this word order pattern among the younger generation. This mirrors the trend observed for negative utterances (Kennard 2014), and that noted by Avezard-Roger (2004). The stigmatisation of French-influenced Breton is clearly having an impact on younger speakers' choices about word order patterns. French influence in Breton more generally receives bad press: Dressler (1991) mentions the French-accented Breton termed roazhonek, which might be translated as "Breton as spoken in Rennes [Roazhon]", where there are no native Breton speakers. Davalan's (2003) textbook for Breton learners remarks that subject-initial word order is characteristic of learners' Breton, and Neo-Breton speakers are therefore likely to be aware of this stigmatisation of French word order patterns. As Hornsby (2017) writes, Neo-Breton speakers are sometimes told by traditional native speakers that their Breton is in some way 'inauthentic', whether due to the accent, the Celticised lexicon, or the syntax. Speakers may therefore avoid anything they perceive to be French influence in their Breton. More widely, this avoidance is contributing to a loss of regional variation in Neo-Breton: the Breton taught in schools and used for modern written texts is a standardised form of the language, which in itself is likely to reduce the use of local variants. If one of these variants is maligned as 
indicating poor proficiency in Breton, and unwanted influence from French, then naturally speakers will seek alternatives to it.

The use of Vnfin-initial word order in progressive utterances is particularly interesting. Among the older speakers, this is never found with an all-focus reading as demanded by the task, but for some younger speakers, both young adults and children, it is a major alternative pattern. It seems possible that the use of this pattern in progressive utterances is in analogy with the Vnfin-initial pattern found in non-progressive utterances. However, while these two constructions may appear to be very similar, both placing the nonfinite verb in initial position, in fact they are quite different, which has further implications for an analysis of word order among the younger generation of speakers. In the progressive utterances, the fronted element is a phrase, while in non-progressive utterances, the fronted element is a head. We can therefore make a distinction between VP-fronting and V-fronting.

a. V-fronting

$\begin{array}{lllll}\text { lenn a ra } & \text { Soazig } & \text { al } & \text { levr } \\ \text { read.vN PRT } & \text { do.3SG } & \text { Soazig } & \text { DET } & \text { book } \\ \text { 'Soazig reads the book.' }\end{array}$

b. VP-fronting

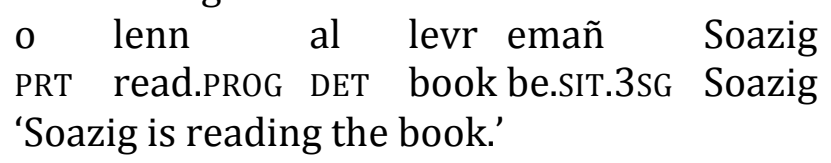

Not all V2 languages can place both heads and phrases in the initial position, with some allowing only phrases (Jouitteau 2010b). Breton allows both C-heads, such as the negative particle ne, and the non-finite verb to occupy this position. V-fronting, also known as Long Head Movement has been discussed by Borsley et al. (1996), Schafer (1997), Tallerman (1997) and Borsley \& Kathol (2000) among others. These accounts demonstrate that V-fronting has a number of distinctive features, which can be found cross-linguistically, and in two of these it contrasts with VP-fronting. First, V-fronting is clause-bound, while VP-fronting is not. Example (29a) is ungrammatical because the past participle has been fronted from the embedded clause.

Clause-bound

a. V-fronting (Borsley \& Kathol 2000: 693)

*[desket] am eus $\quad$ klevet he deus Anna he c'hentelioù
learn.PP 1SG have.1SG hear.PP 3 SSG.F have.3SG.F Anna
('I have heard that Anna has learnt her lessons.')

b. VP-fronting (Borsley \& Kathol 2000: 694)

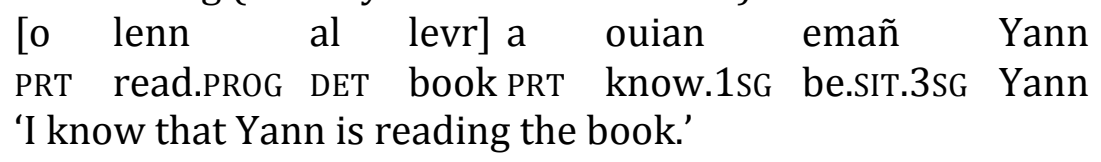

Secondly, V-fronting cannot occur in negative clauses, while VP-fronting is grammatical in negatives: 
a. V-fronting (Borsley \& Kathol 2000: 700)

$\begin{array}{llllll}\text { *lenn ne ra ket Yann } & \text { al levr } \\ \text { read.vn NEG do.3SG NEG } & \text { Yann } & \text { DET } & \text { book } \\ \text { ('Yann doesn't read the book.') } & & \end{array}$

b. VP-fronting (Borsley, et al. 1996: 56)

$\begin{array}{llllll}\text { o lenn al levr n' } & \text { emañ } & \text { ket } & \text { Yann } \\ \text { PRT read.PROG } & \text { DET } & \text { book NEG } & \text { be.SIT.3SG } & \text { NEG } & \text { Yann } \\ \text { 'Yann isn't reading the book.' } & & & \end{array}$

In addition, there are two further main features of V-fronting: first, it is restricted to root clauses, and cannot appear in embedded clauses, which have VSO word order. ${ }^{18}$ In (31), both the main clause and the embedded clause have V-fronting, and it is the V-fronting in the embedded clause that makes it ungrammatical.

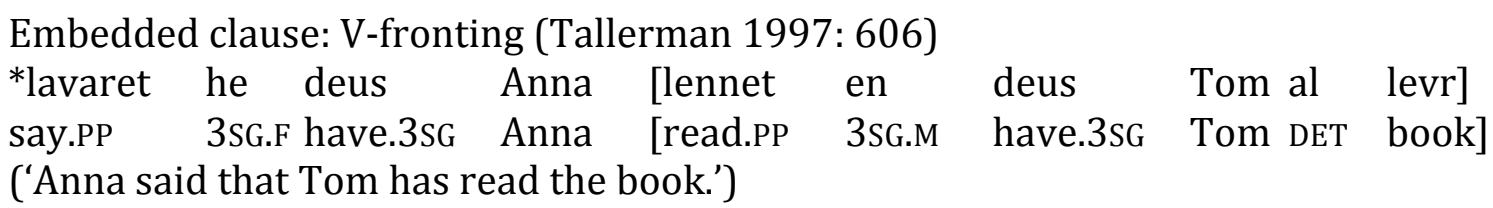

Secondly, V-fronting cannot co-occur with topicalisation of a phrase, resulting in ungrammaticality in (32).

Topicalisation of a phrase: V-fronting (Borsley, et al. 1996: 60)

*al levr lennet en deus Tom

DET book read.PP 3SG.M have.3SG Tom

('Tom has read the book.')

All of this means that V-fronting in non-progressive utterances and VP-fronting in progressive utterances should not be regarded as equivalent: an initial VP in a progressive utterance would ordinarily receive narrow focus. A Minimalist account such as Jouitteau's (2010a) model captures this contrast: under this analysis, a fronted head and a fronted phrase occupy different positions in the left periphery, or CP domain. Fronted phrases, like the initial VP, appear in the specifier of Foc(us)P, while fronted heads, like the initial VN, appear in the specifier of Fin(iteness)P. The fronted VP therefore receives focus, while the fronted V appears in a position with no informational structure relations, but where it is still higher in the structure than the finite verb. It is therefore neither topic nor focus. While this appears to hold true for the senior adults, who never use Vnfin-initial word order in wide-focus

\footnotetext{
18 There are some instances where the word order of an embedded clause is V2, and in these cases, V-fronting is permitted. Borsley \& Kathol (2000: 675) give the following example, where the embedded clause is introduced by $h a(g)$ 'whether' and the order is V2; V-fronting is perfectly grammatical. (I am grateful to an anonymous reviewer for pointing this out.)

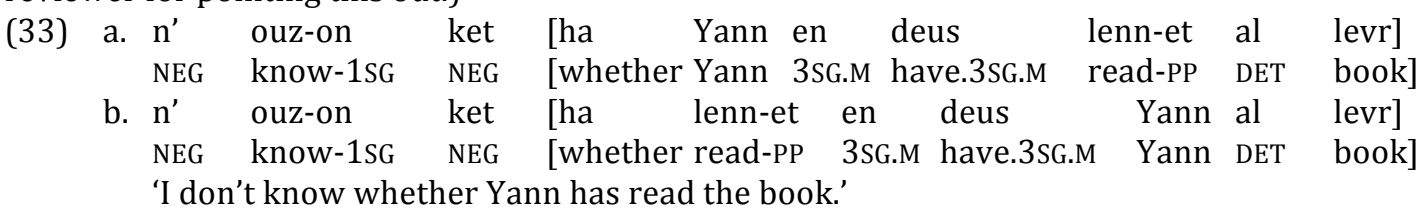


progressive utterances, some of the younger speakers (e.g. VY and, to some extent, E) seem to violate this constraint; however, they are not representative of the younger speaker cohort as a whole, and it would be premature to claim that VP-fronting is becoming less marked among Neo-Breton speakers as a group. If this word order usage were to spread beyond a few individuals to speakers of Neo-Breton more widely, potentially as a result of the avoidance of S-initial word order, then this might herald significant changes to the grammar of Breton. This in turn would widen the gap between the two generations of speakers.

A final interesting point is to be found in the difference between the two groups of children based on the type of school they attend. There seems to be a tendency among the children attending a Diwan school to use non-Subject-initial word order more frequently in comparison with children attending DivYezh classes. A similar contrast was found in Kennard (2014). In the Diwan system, there is a policy of total immersion in Breton: children start from age 2 with all of their classes in Breton, and French is gradually incorporated at a later stage (Kuter 1999). In the bilingual DivYezh system, the goal is to give equal time to each language at the primary level, and children learn to read and write in French before they learn to read and write in Breton. Many classes bilingues take place in the context of a 'normal' French primary school, so that at break times the children are surrounded by a French-speaking environment. Naturally, children at Diwan schools receive more input in Breton at an early age than the DivYezh children do, and this may be playing a role in their word order usage. The greater proportion of Subject-initial utterances among the DivYezh children is therefore likely to be due to increased French influence. However, the young adults' word order usage shows little variation that can be attributed to factors such as the type of schooling they attended, and so it is likely that this slight difference between the two groups of children (it can only be observed in progressive utterances) will disappear as the children grow older and the DivYezh group are exposed to more Breton.

\section{CONCLUSIONS}

An investigation into word order variation in Breton is not a straightforward task: the many and varied word order patterns available to speakers are further complicated by the gap between traditional and Neo-Breton speakers. However, the results of this study confirm that Breton has a V2 constraint in matrix clauses, and that the choice of the initial constituent is largely pragmatic: the focused constituent is fronted to the initial position. If the context is neutral, that is, if there is no focused constituent to place in this initial position, word order is heavily influenced by the nature of the subject. Lexical subjects are likely to be placed in initial position, while pronominal subjects may not be expressed, with the result that Long Head Movement is used, placing the nonfinite verb in initial position. This ties in with Le Roux's (1957) observations and also with Jouitteau's (2011) theoretical stance on word order in wide-focus utterances.

Among the older generation of speakers, regional features also seem to play a role. Speakers from the southwest of Brittany (like those in this study) seem to prefer subjectinitial word order when there is no focused constituent (Avezard-Roger 2004). This regional variation seems to be being lost among speakers of Neo-Breton: while they show a preference 
for subject-initial word order with lexical subjects (like the traditional speakers), when the subject is pronominal they tend to prefer alternative word order patterns, such as Vnfininitial word order, and Vfin-initial word order in progressive utterances. Rather than French influence in Breton syntax leading to an increase in subject-initial word order, apart from among less proficient younger speakers, it seems to have resulted in avoidance of this word order pattern when possible. Nevertheless, the majority of Neo-Breton speakers have not gone so far as to avoid subject-initial word order in utterances with a lexical subject, and so some of the patterns found in the older generation are being maintained. Only time will tell how the variation among speakers of Neo-Breton will develop in the future. 
Anderson, Stephen R., 1981. 'Topicalization in Breton' Proceedings of the Annual Meeting of the Berkeley Linguistics Society 7, 27-39.

Anderson, StEPHEn R., 2005. Aspects of the Theory of Clitics, Oxford: Oxford University Press.

ANDERSON, STEPHEN R. \& CHUnG, SANDRA, 1977. 'On grammatical relations and clause structure in verb-initial languages', in Peter Cole \& Jerrold M. Saddock (eds.), Grammatical Relations, New York: Academic Press, 1-25.

AvEZARD, CÉCILE, 1999. 'La dynamique linguistique du breton', in Pierre Parlebas (ed.) Le corps et le langage: parcours accidentés, Paris: L'Harmattan, 73-92.

AvEZARD-Roger, CÉCILE, 2004. 'Proximité linguistique entre breton standard et breton dialectal et entre breton et français : le cas des structures verbales', in Jean-Michel Eloy (ed.) Des langues collatérales: Problèmes linguistiques, sociolinguistiques et glottopolitiques de la proximité linguistique, Paris: L'Harmattan, II: 485-94.

Borsley, Robert D. \& Kathol, Andreas, 2000. 'Breton as a V2 language' Linguistics 38(4), 665710.

Borsley, Robert D., Rivero, Maria-Luisa \& Stephens, Janig, 1996. 'Long Head Movement in Breton', in Robert D. Borsley \& Ian Roberts (eds.), The syntax of the Celtic languages: A comparative perspective, Cambridge: Cambridge University Press, 53-74.

Borsley, Robert D., Tallerman, Maggie \& Willis, David, (eds.) 2007. The Syntax of Welsh, Cambridge: Cambridge University Press.

Brody, JILL, 1984. 'Some problems with the concept of basic word order' Linguistics 22(5), 711-36.

Broudic, FAÑCH, 2009. Parler breton au XXIe siècle: Le nouveau sondage de TMO-Régions, Brest: Emgleo Breiz.

Davalan, Nikolaz, 2003. Brezhoneg Hentenn Oulpan 2, Rennes: Skol an Emsav.

Delanoy, ARnaud, 1990. 'Breton and the Word Order Concept' Word 41(2), 219-21.

DENIS, PIERRE, 1977. 'Etude structurale d'un parler breton', Doctorat ès lettres, Université de Haute Bretagne.

DRESSLER, WolfGang U., 1991. 'The sociolinguistic and patholinguistic attrition of Breton phonology, morphology and morphonology', in Herbert W. Seliger \& Robert Michael Vago (eds.), First Language Attrition, Cambridge: Cambridge University Press, 99-112.

Dressler, Wolfgang U. \& Hufgard, Josef, 1980. Études phonologiques sur le breton sudbigouden, Wien: Verlag der Österreichischen Akademie der Wissenschaften.

Dryer, MatThew S., 2007. 'Word order', in Timothy Shopen (ed.) Language typology and syntactic description: Volume 1. Clause Structure, Cambridge: Cambridge University Press, 61-131.

German, GarY, 2007. 'Language Shift, Diglossia and Dialectal Variation in Western Brittany: the Case of Southern Cornouaille', in Hildegard L. C. Tristram (ed.) The Celtic Languages in Contact: Papers from the Workshop within the Framework of the XIII International Congress of Celtic Studies, Bonn, 26-27 July 2007, Potsdam: Potsdam University Press, 146-92.

HeIne, BERnd, 2006. 'Contact-induced word order change without word order change' Working Papers in Multilingualism. Series B 76, 1-24.

Heine, Bernd \& Kuteva, Tania, 2005. Language Contact and Grammatical Change, Cambridge: Cambridge University Press.

HEWITT, STEVE, 2002. 'The Impersonal in Breton' Journal of Celtic Linguistics 7, 1-38.

Hornsby, Michael, 2005. 'Néo breton and questions of authenticity' Estudios de Sociolingüística 6(2), 191-218. 
Hornsby, Michael, 2015. 'The "new" and "traditional" speaker dichotomy: bridging the gap' International Journal of the Sociology of Language 2015(231), 107-25.

HoRnsby, MichaEl, 2017. 'Finding an ideological niche for new speakers in a minoritised language community' Language, Culture and Curriculum 30(1), 91-104.

Jackson, Kenneth Hurlstone, 1967. A historical phonology of Breton, Dublin: Dublin Institute for Advanced Studies.

JafFe, AleXANDRA, 2015. 'Defining the new speaker: theoretical perspectives and learner trajectories' International Journal of the Sociology of Language 2015(231), 21-44.

Jones, MARI C., 1995. 'At What Price Language Maintenance? Standardization in Modern Breton' French Studies: A Quarterly Review 49(4), 424-38.

Jouin, BeATris, 1984. Petite grammaire du Breton, Rennes: Ouest France.

JouitTEAU, MÉlanie, 2005. 'La syntaxe comparée du Breton', unpublished doctoral thesis, Université de Naoned/Nantes.

JouitTEAU, MÉlanie, 2007. 'The Brythonic Reconciliation: From verb-first to generalized verbsecond' Linguistic Variation Yearbook 7, 163-200.

JouitTEAU, MÉLANIE, 2010a. La syntaxe comparée du breton: une enquête sur la périphérie gauche de la phrase bretonne, Saarbrücken: Éditions universitaires européennes.

JouitTeau, MÉlanie, 2010b. 'A typology of V2 with regard to V1 and second position phenomena: An introduction to the V1/V2 volume' Lingua 120(2), 197-209.

JouitTeAu, Mélanie, 2011. 'Post-syntactic Excorporation in Realizational Morphology: Breton Analytic Tenses', in Andrew Carnie (ed.) Formal Approaches to Celtic Linguistics, Newcastle upon Tyne: Cambridge Scholars Publishing, 115-42.

JouitTEAU, MÉlanie, $2017 . \quad$ 'Bezañ http://arbres.iker.cnrs.fr/index.php?title=Bezan_pr\%C3\%A9verbal [Accessed: 3/8/2017].

Kennard, Holly J., 2014. 'The persistence of verb second in negative utterances in Breton' Journal of Historical Linguistics 4(1), 1-39.

KENNARD, Holly J., 2018. 'Verbal mutation among young speakers of Breton: Acquisition and maintenance', in Michael Hornsby, Máiréad Moriarty, Cassie Smith-Christmas \& Noel Ó Murchadha (eds.), New Speakers of Minority Languages: Linguistic Ideologies and Practices, Basingstoke: Palgrave Macmillan, 231-52.

Kennard, Holly J. \& LAHIRI, AdITI, 2017. 'Mutation in Breton verbs: Pertinacity across generations' Journal of Linguistics 53(1), 113-45.

KERRAIN, MARK, 1995. Ni a gomz brezhoneg! Nous, nous parlons breton!, Roazhon: TES.

KERVELla, FraÑSEZ, 1947. Yezhadur bras ar brezhoneg, La Baule: Skridou Breizh.

Kuter, LoIs, 1999. 'The Diwan Phenomenon: A Catalyst for Change in the Schools of Brittany', in Philippe Blanchet, Roland Breton \& Harold Schiffman (eds.), Les langues régionales de France: un état des lieux à la veille du XXIe siècle. Actes d'un colloque organisé à "The University of Pennsylvania, Philadelphia, USA», Louvain-la-Neuve: Peeters, 177-83.

LE Dû, JEAn, 2011. Du café vous aurez ? Quand les bretons parlent le français, Brest: Emgleo Breiz.

LE Roux, PIERRE, 1957. Le verbe breton, Rennes: Plihon.

McDonald, J. H., 2014. Handbook of Biological Statistics (3rd ed.), Baltimore, Maryland: Sparky House Publishing.

McDonald, Maryon, 1989. 'We are not French!' Language, culture and identity in Brittany, London; New York: Routledge.

MEelen, MARIEKE, 2016. Why Jesus and Job spoke bad Welsh: the origin and distribution of V2 orders in Middle Welsh, Utrecht: LOT.

O'Rourke, Bernadette, Pujolar, JoAn \& Ramallo, Fernando, 2015. 'New speakers of minority languages: the challenging opportunity - Foreword' International Journal of the Sociology of Language 2015(231), 1-20. 
Press, J. IAN, 1986. A Grammar of Modern Breton, Berlin: Mouton de Gruyter.

Press, J. IAN, 2009. 'Breton', in Martin J. Ball \& Nicole Müller (eds.), The Celtic Languages, London; New York: Routledge, 427-87.

RANeY, Roslyn, 1984. 'VSO and SVO order in Welsh and Breton' Papers and Studies in Contrastive Linguistics 18, 47-54.

SCHAFER, RoBin JaYne, 1997. 'Long head movement and information packaging in Breton' Canadian Journal of Linguistics/Revue canadienne de linguistique 42(1-2), 169-203.

Schapansky, Nathalie, 2000. Negation, Referentiality and Boundedness in Gwenedeg Breton: A Case Study in Markedness and Asymmetry, München: Lincom Europa.

SonG, JAE Jung, 2012. Word Order, Cambridge: Cambridge University Press.

STEPHENS, JANiG, 1982. 'Word order in Breton', unpublished doctoral thesis, School of Oriental and African Studies, University of London.

Stephens, JAniG, 1983. 'The Neutral Sentence in Breton', in D. Ellis Evans, John G. Griffith \& E. M. Jope (eds.), Proceedings of the Seventh International Congress of Celtic Studies, Oxford: Cranham Press, 304-5.

Stump, Gregory T., 1984. 'Agreement vs. Incorporation in Breton' Natural Language \& Linguistic Theory 2(3), 289-348.

TAllerman, MagGie, 1997. 'Celtic word order: some theoretical issues', in Anna Siewierska (ed.) Constituent Order in the Languages of Europe, Berlin; New York: Mouton de Gruyter, 599-648.

Tallerman, Maggie, 2005. 'The Celtic Languages', in Guglielmo Cinque \& Richard S. Kayne (eds.), The Oxford Handbook of Comparative Syntax, Oxford: Oxford University Press, 839-79.

Timm, LENORA A., 1989. 'Word order in twentieth-century Breton' Natural Language \& Linguistic Theory 7(3), 361-78.

Timm, LenORA A., 1991. 'The Discourse Pragmatics of NP-initial Sentences in Breton', in James Fife \& Erich Poppe (eds.), Studies in Brythonic Word Order, Amsterdam: John Benjamins, 275-310.

VARIN, AMY, 1979. 'VSO and SVO Order in Breton' Archivum Linguisticum 10 (new series), 83101.

Willis, DaVID W. E., 1998. Syntactic Change in Welsh: A Study of the Loss of Verb-Second, Oxford: Clarendon Press.

WoJcik, RICHARD, 1976a. 'The copula as auxiliary in a surface VSO language', in Salikoko S. Mufwene, Carol A. Walker \& Sanford B. Steever (eds.), Papers from the Twelfth Regional Meeting, Chicago: Chicago Linguistic Society, 666-75.

WoJcik, Richard, 1976b. 'Verb Fronting and Auxiliary do in Breton' Recherches Linguistiques à Montréal 6, 259-78. 